\title{
Identification and Subcellular Localization of Human Rab5b, a New Member of the Ras-related Superfamily of GTPases
}

\author{
David B. Wilson* and Monita P. Wilson* \\ *Division of Hematology-Oncology, Boston Children's Hospital, Dana Farber Cancer Institute, Boston, Massachusetts 02115; and \\ ${ }^{\ddagger}$ Graduate Department of Biochemistry, Center for Complex Systems, Brandeis University, Waltham, Massachusetts 02254
}

\begin{abstract}
Members of the mammalian rab family of GTPases are associated with specific subcellular compartments, where these proteins are postulated to function in vesicular transport. By screening a human umbilical vein endothelial cell library with degenerate oligonucleotide probes, we have isolated a 1.6-kb cDNA clone encoding a 215-amino-acid protein belonging to the rab family of GTPases. This newly identified rab protein is $81 \%$ identical to human rab5, the canine counterpart of which has been localized to the plasma membrane and early endosomes. In light of this homology, we have named this new member of the GTPase superfamily "rab5b." Northern analysis using the rab5b cDNA as a probe revealed a 3.6-kb mRNA in a variety of cell types, including human umbilical vein endothelial cells, K562 erythroleukemia cells, U937 monoblastic cells, and HeLa cells. A fusion protein between glutathione-Stransferase (GST) and rab5b was expressed in bacteria and purified to homogeneity. The recombinant protein was shown to bind GTP and GDP. As is typical of other recombinant rab proteins, the rab5b-GST fusion protein displayed a low intrinsic rate of GTP hydrolysis $(0.005 / \mathrm{min})$. An antiserum to $\mathrm{rab5b}$ was prepared and used to determine the apparent molecular size and subcellular distribution of the protein. Western blotting with this antibody revealed a $25-\mathrm{kD}$ protein in COS cells transfected with rab5b and in nontransfected HeLa cells. Indirect immunofluorescence and subcellular fractionation showed that rab5b localizes to the plasma membrane. We speculate that rab5b plays a role in vesicular trafficking at the plasma membrane in various cell types. (J. Clin. Invest. 1992. 89:9961005.) Key words: GTP-binding protein $•$ membrane trafficking
\end{abstract}

\section{Introduction}

A number of processes in eukaryotic cells are believed to be regulated by small, monomeric GTPases belonging to the ras superfamily (1-3). Members of this superfamily include the ras, ral, rho, rac, rap, and rab gene products in mammalian cells and the YPTI/SEC4 gene products in yeast. Proteins in the ras superfamily share $\geq 30 \%$ homology to the ras gene product. This homology reflects conservation of a series of sequence motifs that contribute to the guanine nucleotide binding do-

Address reprint requests to Dr. David B. Wilson, Division of Hematology, Enders Building, 7th Floor, Boston Children's Hospital, 300 Longwood Avenue, Boston, MA 02115.

Received for publication 17 June 1991 and in revised form 23 October 1991.

J. Clin. Invest.

(c) The American Society for Clinical Investigation, Inc.

0021-9738/92/03/0996/10 \$2.00

Volume 89, March 1992, 996-1005 main (4). Ras-related GTPases are thought to act as molecular switches that alternate between GTP- and GDP-bound conformational states $(1,2)$. The switching function of each GTPase is determined by the differing affinities of the conformational states for effector molecules $(1,2)$.

Recent studies suggest that a subset of these GTPases (the yeast YPTI/SEC4 gene products and their mammalian counterparts the rab proteins) plays a central role in membrane trafficking (1-13). By alternating between the GTP- and GDPbound conformational states, these proteins are postulated to direct fusion of exocytic or endocytic vesicles with membrane acceptors. A number of proteins belonging to this subfamily have been identified; each of these proteins is thought to regulate vesicular trafficking at a specific subcellular compartment. The subcellular locations of several rab proteins have been determined by immunohistochemical methods. Rab2 is found in the intermediate recycling pathway between the endoplasmic reticulum and Golgi complex (11). Rab6 is distributed in the medial and trans Golgi (13). Rab4 and rab5 are associated with the plasma membrane and early endosomes, whereas rab7 localizes to late endosomes $(8,11,12)$. Rab3a is associated with the secretory vesicles of neurons and neuroectodermal cells (14-17).

Several lines of evidence support a functional role for the $\mathrm{rab}$ and YPT1/SEC4 proteins in membrane trafficking. In cellfree assay systems, low concentrations of nonhydrolyzable GTP analogues have been shown to inhibit various steps of the secretory and endocytic pathways (18-23). Synthetic peptides corresponding to the surface residues of rab proteins have been found to inhibit vesicular transport through the secretory pathway in vitro (24). An antibody against one of the rab proteins (rab5) has been shown to inhibit vesicle fusion in cell-free extracts (25). Moreover, a nonhydrolyzing mutant of rab5 has been prepared and shown to competitively inhibit early endosome fusion in vitro (25). The association and dissociation of rab3a with synaptic vesicles have been shown to correlate with the secretory process (16). In yeast, the functional importance of this subfamily of GTPases has been established through isolation and characterization of secretory mutants. Temperature-sensitive yeast YPTI mutants exhibit abnormal transport of vesicles between the endoplasmic reticulum and Golgi, whereas temperature-sensitive mutations in SEC4 disrupt a late step in the exocytic pathway (26-28).

In this study we describe the cDNA cloning of a novel member of the rab family, obtained by screening a human umbilical vein endothelial cell cDNA library with oligonucleotide probes corresponding to a region conserved in all rab proteins. We show that this new member of the rab family binds guanine nucleotides in vitro and exhibits GTPase activity. Furthermore, we demonstrate that the protein is expressed in a variety of cells and localizes to the plasma membrane. We propose that this newly identified GTPase, like other members of 
the rab family, plays a role in controlling membrane trafficking in cells.

\section{Methods}

Isolation of a cDNA encoding human rab5b. A randomly primed lambda gt 11 human endothelial cell cDNA library (29) was screened with a 1:1 mixture of the following two degenerate oligonucleotide probes corresponding to the sequence WDTAGQE, which is conserved in all rab proteins: Probe $A$, TGGGACACAGC $\left(A_{50} / T_{50}\right) G G\left(G_{25} / A_{25} /\right.$ $\left.\mathrm{T}_{25} / \mathrm{C}_{25}\right)$ CAGGAG; Probe B, TGGGACACTGC(A/T)GG $\left(\mathrm{G}_{25} / \mathrm{A}_{25} /\right.$ $\left.\mathrm{T}_{25} / \mathrm{C}_{25}\right)$ CAGGAG. The oligonucleotide mixture was end labeled to a specific activity of $0.3 \times 10^{6} \mathrm{cpm} / \mathrm{ng}$ using [ $\left.\gamma-{ }^{32} \mathrm{P}\right] \mathrm{ATP}$ and polynucleotide kinase (30). A total of 600,000 plaques was screened in duplicate (Hybond-N filters; Amersham Corp., Arlington Heights, IL). The filters were prehybridized overnight at $4^{\circ} \mathrm{C}$ in $3 \mathrm{M}$ tetramethylammonium chloride, $10 \mathrm{mM}$ sodium phosphate, $\mathrm{pH} 6.8,1 \mathrm{mM}$ EDTA, $0.5 \%$ SDS, $100 \mu \mathrm{g} / \mathrm{ml}$ boiled sonicated salmon sperm DNA, and $0.1 \%$ powdered milk (30). The filters were then hybridized overnight at $48^{\circ} \mathrm{C}$ with $5 \times 10^{6} \mathrm{cpm} / \mathrm{ml}$ of probe in $3 \mathrm{M}$ tetramethylammonium chloride, $10 \mathrm{mM}$ sodium phosphate, $\mathrm{pH}$ 6.8, $1 \mathrm{mM}$ EDTA, 0.5\% SDS, 200 $\mu \mathrm{g} / \mathrm{ml}$ boiled sonicated salmon sperm DNA, and $0.1 \%$ powdered milk. The filters were washed three times, 5 min each, in $6 \times$ standard saline citrate (SSC) at room temperature and autoradiographed overnight. Phage DNA was isolated from a hybridizing plaque (30). A 1.6-kb cDNA insert encoding rab5b was liberated by EcoRI digestion and subcloned into the EcoRI site of pUC19.

Isolation of genomic clones for human rab5b. A human genomic library in $\mathrm{EMBL}_{3}$ was screened with the 1.6-kb rab5b cDNA under previously described hybridization conditions (31). Overlapping genomic clones encoding rab5b were obtained. Inserts were liberated from the clones by digestion with EcoRI and then subcloned into the EcoRI site of Bluescript $\mathrm{SK}^{+}$.

DNA sequencing. Nucleotide sequences were determined using the dideoxynucleotide method (32) with Sequenase (United States Biochemical Corp., Cleveland, $\mathrm{OH}$ ) and synthetic oligonucleotide primers.

Cell culture. HeLa, K562, U937, COS, and human umbilical vein endothelial cells were maintained in culture as previously described (31). Where indicated, K562 cells were induced with hemin before harvesting (33). EAhy.926 cells, a hybrid cell line between human endothelial cells and a lung carcinoma line provided by C. S. Edgell, University of North Carolina, were maintained as described (34).

RNA isolation and Northern blot analysis. RNA was isolated using the acidified guanidinium thiocyanate phenol method (35). Poly-A RNA was isolated by oligo-dT chromatography (30). Conditions for Northern blot analysis have been previously described (31). Probes for Northern analysis were radiolabeled with $\left[\alpha-{ }^{32} \mathrm{P}\right] \mathrm{dCTP}$ by random hexanucleotide priming (30). The presence of intact mRNA was confirmed by probing with a ${ }^{32} \mathrm{P}$-labeled $\alpha$-tubulin cDNA.

Expression of a rab5b fusion protein in Escherichia coli. The 1.6-kb EcoRI cDNA fragment encoding rab5b was cloned into the EcoRI site of pGEX3X (Amersham Corp.). The resulting plasmid encoded a protein consisting of glutathione- $S$-transferase (GST) ${ }^{1}$ fused to rab5b via the 19-amino-acid linker GNSLQYPGGSTLSDSDNLA (introduced by cloning the cDNA fragment into the vector). This plasmid was used to transform the $E$. coli strain DH5 $\alpha$. A $50-\mathrm{ml}$ overnight culture of the transformed cells, in LB medium (30) supplemented with $50 \mu \mathrm{g} / \mathrm{ml}$ ampicillin, was diluted 1:10 into this same culture medium and grown for $3 \mathrm{~h}$ at $37^{\circ} \mathrm{C}$. Expression of the GST-rab5b fusion protein was then induced by addition of $0.1 \mathrm{mM}$ isopropyl- $\beta$-D-thiogalactoside (IPTG). After 90 min of incubation with IPTG, bacteria from the $500-\mathrm{ml} \mathrm{cul}-$ ture were isolated by centrifugation; resuspended in $50 \mathrm{ml}$ of PBS con-

1. Abbreviations used in this paper: GST, glutathione-S-transferase; IPTG, isopropyl- $\beta$-D-thiogalactoside. taining $1 \%$ Triton X-100, $50 \mathrm{mM}$ EDTA, $80 \mu \mathrm{g} / \mathrm{ml}$ PMSF, $0.4 \%$ aprotinin, $2 \mu \mathrm{g} / \mathrm{ml}$ leupeptin, $2 \mu \mathrm{g} / \mathrm{ml}$ pepstatin, and $1 \mathrm{mM} \mathrm{DTT}$; and sonicated for $30 \mathrm{~s}$. After centrifugation at $14,000 \mathrm{~g}$, the supernatant fraction containing solubilized fusion protein was applied to a 1-ml glutathione-agarose column (Pharmacia Fine Chemicals, Piscataway, NJ). The GST-rab5b fusion protein was eluted with $15 \mathrm{mM}$ glutathione as described (36). The purified protein was dialyzed against PBS and stored at $-70^{\circ} \mathrm{C}$. The typical yield of purified GST-rab5b was $1 \mathrm{mg} /$ $500 \mathrm{ml}$ bacterial culture. For use as a control, purified GST was prepared by affinity chromatography of an extract of DH $5 \alpha$ cells transformed with pGEX3X.

Assays of GTP binding, GTPase activity, and GDP dissociation. Purified GST-rab5b and GST were run on SDS-PAGE (37) and then electrophoretically transferred to nitrocellulose filters. The filters were incubated with $\left[{ }^{32} \mathrm{P}-\alpha\right]$ GTP (Amersham Corp.) as described by Schmitt et al. (38). Competition for GTP binding was performed as described elsewhere (7). GTPase activity of the purified GST-rab5b was measured as described (7). The GTPase reactions contained $10 \mu \mathrm{M}\left[\alpha-{ }^{32} \mathrm{P}\right]$ GTP $(10 \mathrm{mCi} / \mu \mathrm{mol}), 10 \mathrm{mM} \mathrm{Mg}^{2+}$, and 1-2 $\mu \mathrm{M} \mathrm{GST-rab5b;} \mathrm{incuba-}$ tions were carried out at $37^{\circ} \mathrm{C}$. GDP dissociation from GST-rab5b was measured using the exchange assay of John et al. (39). The reaction mixture contained $2 \mu \mathrm{M}$ GST-rab5b, $10 \mu \mathrm{M}\left[8-{ }^{3} \mathrm{H}\right] \mathrm{GDP}(300 \mathrm{CPM} /$ pmol), and $10 \mathrm{mM} \mathrm{Mg}^{2+}$. Incubations were carried out at $37^{\circ} \mathrm{C}$.

Expression of rab5b in COS cells. The 1.6-kb EcoRI cDNA fragment encoding rab5b was cloned into the EcoRI site of the eukaryotic expression vector pMT2 (33). COS cells in $100-\mathrm{mm}$ diam petri dishes were transfected with $5 \mu \mathrm{g}$ of pMT2-rab5b using DEAE-dextran (33). Cytosolic and membrane extracts (33) were prepared 48-72 $\mathrm{h}$ after transfection.

Preparation of rabbit antisera. The synthetic peptide SEPQNLGGAAGRSC corresponding to amino acids 184-196 of rab5b was commercially prepared (Research Genetics, Huntsville, $\mathrm{AL}$ ). The peptide was coupled to keyhole limpet hemocyanin with glutaraldehyde (40), and the keyhole limpet hemocyanin-peptide conjugate was used to immunize rabbits by intradermal injection (40). For antibody purification an affinity resin was prepared by coupling $4 \mathrm{mg}$ of rab5b peptide to $2 \mathrm{ml}$ of Affi-gel 10 (Bio-Rad Laboratories, Richmond, CA) using the manufacturer's instructions. The affinity resin was equilibrated with 50 $\mathrm{mM}$ Tris- $\mathrm{HCl} \mathrm{pH} 8$ and $500 \mathrm{mM} \mathrm{NaCl}$, and then $20 \mathrm{ml}$ of antiserum (dialyzed against this same buffer) was applied. After washing, antibodies were eluted with $10 \mathrm{ml}$ of $4 \mathrm{M} \mathrm{MgCl}_{2}$. The eluted antibodies were dialyzed against $50 \mathrm{mM}$ Tris- $\mathrm{HCl} \mathrm{pH} 8,500 \mathrm{mM} \mathrm{NaCl}$, and $0.05 \%$ $\mathrm{NaN}_{3}$ and stored at $4^{\circ} \mathrm{C}$.

Western blotting. SDS-PAGE and electrophoretic transfer to nitrocellulose membranes were performed as described (40). Immunoreactive protein was visualized by incubation with rabbit antiserum to rab5b (1:2,000 dilution), followed by alkaline phosphatase-conjugated goat anti-rabbit IgG (1:8,000 dilution). The alkaline phosphatase reaction was run with bromochloroindolyl phosphate and nitro blue tetrazolium (40).

Immunofluorescence. COS cells grown on cover slips were transfected with pMT2 or pMT2-rab5b as described above. After $48 \mathrm{~h}$, the cells were washed with PBS and permeabilized for $5 \mathrm{~min}$ with $80 \mathrm{mM}$ Na-Pipes [piperazine- $N, N^{\prime}$-bis(2-ethanesulfonic acid), pH 6.8], $5 \mathrm{mM}$ EGTA, $1 \mathrm{mM} \mathrm{MgCl}$, and $0.1 \%$ Tween-20. The cells were fixed with $3.7 \%$ formaldehyde in PBS for $15 \mathrm{~min}$. After fixation, the cells were washed with PBS containing $0.1 \%$ Tween-20. The cells were then incubated for 10 min with PBS containing $0.1 \%$ Tween-20 and 5\% powdered milk to decrease nonspecific binding. A 1:200 dilution of affinity purified anti-peptide antibody in PBS containing $0.1 \%$ Tween-20 and $5 \%$ powdered milk was applied for $20 \mathrm{~min}$. The cells were then washed four times with $0.1 \%$ Tween-20 in PBS. A 1:2,000 dilution of FITC-labeled goat anti-rabbit IgG $\mathrm{F}\left(\mathrm{ab}^{\prime}\right) 2$ (Tago) in PBS containing $0.1 \%$ Tween and 5\% powdered milk in PBS was applied for $20 \mathrm{~min}$, and then the cells were washed five times with PBS containing 0.1\% Tween-20. The coverslips were mounted on glass slides in $90 \%$ glycerol, $10 \% 100$ $\mathrm{mM}$ Tris-Cl pH 8 and viewed with a photomicroscope (Axioplan; Carl Zeiss, Inc., Thornwood, NY). As a positive control for plasma mem- 
brane immunofluorescence, $\operatorname{COS}$ cells were transfected with expression plasmid pcDNA1-CD64 encoding the human Fc receptor and then stained with mouse monoclonal anti-human Fc receptor IgG, followed by FITC-labeled goat anti-mouse IgG (plasmid and antibody generously provided by R. A. B. Ezekowitz, Boston Children's Hospital). As a negative control, $\mathrm{COS}$ cells were transfected with expression plasmid pXM-GATA-2 encoding human transcription factor GATA-2 (41) and then stained with rabbit antiserum against GATA-2, followed by FITC-labeled goat anti-rabbit IgG F(ab')2 (details of GATA-2 plasmid construction and antiserum preparation will be published elsewhere).

Subcellular fractionation. HeLa cells ( $2.5 \mathrm{mg}$ total protein) were harvested, homogenized, digested with DNase I, and fractionated on a $15 \%$ Percoll gradient using the method of Morand and Kent (42). 10 gradient fractions $(1.3 \mathrm{ml}$ each) were collected. Portions of each fraction were assayed for the following marker enzymes: $\beta$ - $N$-acetylhexosaminidase (43), galactosyltransferase (44), and ouabain-sensitive $\mathrm{Na}^{+} \mathrm{K}^{+}$ATPase (42). A 400- $\mu$ l portion of each gradient fraction was centrifuged at $100,000 \mathrm{~g}$ to remove Percoll and concentrate the membranes; the resultant membrane pellets were subjected to Western blotting using antibody against rab5b. Immunoreactive protein was quantitated by incubation with ${ }^{125}$ I-labeled Protein A (40) followed by phosphoimage analysis (PhosphorImager; Molecular Dynamics, Sunnyvale, CA).

Other methods. Protein concentrations were measured using Bradford reagent (45). Oligonucleotides were synthesized on a 380-b DNA synthesizer (Applied Biosystems, Inc., Foster City, CA) and desalted on NAP-10 columns (Pharmacia Fine Chemicals).

\section{Results}

Molecular cloning of a novel human rab protein. A cDNA encoding a new member of the rab family was isolated using an oligonucleotide screening method similar to that of Touchot et al. (6). A human umbilical vein endothelial cDNA library was screened with degenerate oligonucleotide probes corresponding to WDTAGQE, an amino acid sequence that is conserved in all rab proteins (6). A 1.6-kb cDNA clone was obtained (Fig. 1). On the basis of homology to other ras-related proteins, the ATG codon at position 21 of the cDNA was assumed to be the initiation codon. The protein encoded by this CDNA was found to have a predicted size of $23.7 \mathrm{kD}$, which is typical of other small monomeric GTPases (20-25 kD). In addition to the sequence WDTAGQE (residues 74-80), the predicted protein was found to contain the following sequence motifs, which contribute to the guanine nucleotide binding domain and are conserved in ras-related proteins: GXXXGK (residues 27-33), NKXD (residues 133-136), and EXSAX (residues 161165) (4).

Comparison of the protein encoded by this cDNA with other members of the human rab family (7) revealed the following degrees of sequence homology (given as percentage identical sequence): rab1, 35\%; rab2, 33\%; rab3a, 31\%; rab3b, 30\%; rab4, $31 \%$; rab5, $81 \%$; and rab6, 32\%. Comparison with non-

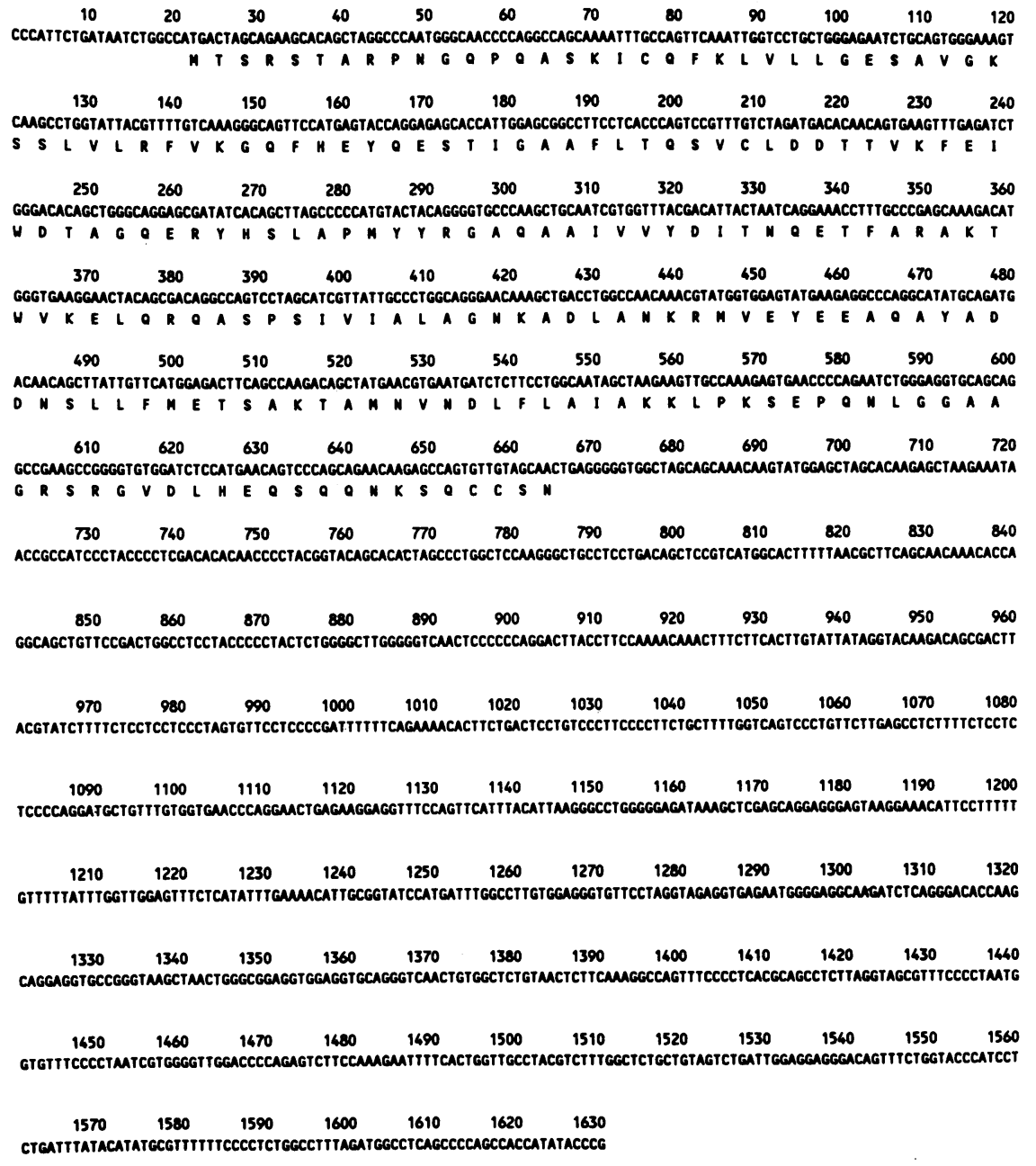

Figure 1. Sequence of a human endothelial cell cDNA encoding a new human rab protein. The ATG codon at nucleotide position 21 was assumed to be the initiation codon on the basis of homology to other ras-related proteins. The translated amino acid sequence is shown in single letter code. The nucleotide sequence of human rab5b has been assigned the EMBL accession number X54871. 
primate rab proteins showed that the protein encoded by the cDNA is most homologous ( $82 \%$ identical) to Madin-Darby canine kidney cell rab5. Since the degree of homology between the newly identified rab protein and rab5 is comparable to the degree of homology between another pair of closely related human rab proteins termed rab3a and rab3b (78\% identical, reference 7), we propose that this newly identified member of the rab family be named "rab5b."

An alignment of the predicted amino acid sequences for human rab5b, human rab5, and canine rab5 is shown in Fig. 2. Although all three proteins are highly homologous, human and canine rab5 are clearly more closely related to each other $(98 \%$ identical) than to human rab5b. The sequence of human rab5b diverges from the two rab5 proteins at the $\mathrm{NH}_{2}$ terminus (residues 1-16) and near the $\mathrm{COOH}$ terminus (residues 184-210). This latter region corresponds to the previously described "hypervariable domain" of ras-related proteins. The sequences of other closely related members of the rab family (e.g., human rab3a and rab3b) also diverge in the $\mathrm{NH}_{2}$-terminal and hypervariable domains (7). Among the three proteins depicted in Fig. 2, there is strict conservation of amino acid sequence in the regions contributing to the guanine nucleotide binding pocket. The putative effector loop of rab5b, predicted on the basis of homology to ras p21 (4) to encompass residues 48-57, differs by one amino acid (Tyr ${ }^{48} \rightarrow$ Phe) from the effector loop of human rab5. Genetic, biochemical, and biophysical analyses of ras p21 have shown that the effector loop mediates the interaction with target/cofactor molecules (e.g., GTPase activating proteins) (reviewed in references 1-4). The similarities between the putative effector domains of rab5b and rab5 suggest that these proteins may interact with similar target molecules.

Small monomeric GTPases of the ras superfamily contain at least one cysteine residue near the $\mathrm{COOH}$ terminus that can undergo posttranslational modification (e.g., prenylation, carboxylmethylation) to enhance membrane association and functional activity (46). The signal for posttranslational modifi-

\begin{tabular}{|c|c|c|}
\hline $\begin{array}{l}\text { h-Rab5b } \\
\text { h-Rab5 } \\
\text { c-Rab5 }\end{array}$ & 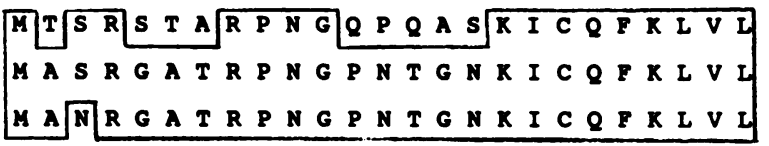 & $\begin{array}{l}25 \\
25\end{array}$ \\
\hline $\begin{array}{l}\text { h-Rab5b } \\
\text { h-Rab5 } \\
\text { c-Rab5 }\end{array}$ & 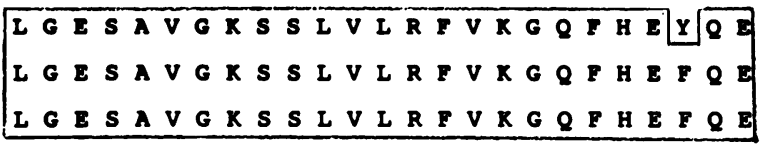 & $\begin{array}{l}50 \\
50 \\
50\end{array}$ \\
\hline $\begin{array}{l}\text { h-Rab5b } \\
\text { h-Rab5 } \\
\text { C-Rab5 }\end{array}$ & \begin{tabular}{|llllllllll|l|llllllllllllll}
$S$ & $T$ & $I$ & $G$ & $A$ & $A$ & $F$ & $L$ & $T$ & $Q$ & $S$ & $V$ & $C$ & $L$ & $D$ & $D$ & $T$ & $T$ & $V$ & $K$ & $F$ & $E$ & $I$ & $W$ & $D$ \\
$S$ & $T$ & $I$ & $G$ & $A$ & $A$ & $F$ & $L$ & $T$ & $Q$ & $T$ & $V$ & $C$ & $L$ & $D$ & $D$ & $T$ & $T$ & $V$ & $K$ & $F$ & $E$ & $I$ & $W$ & $D$ \\
$S$ & $T$ & $I$ & $G$ & $A$ & $A$ & $F$ & $L$ & $T$ & $Q$ & $T$ & $V$ & $C$ & $L$ & $D$ & $D$ & $T$ & $T$ & $V$ & $K$ & $F$ & $E$ & $I$ & $W$ & $D$ \\
\end{tabular} & $\begin{array}{l}75 \\
75 \\
75\end{array}$ \\
\hline $\begin{array}{l}\text { h-Rab5b } \\
\text { h-Rab5 } \\
\text { C-Rab5 }\end{array}$ & 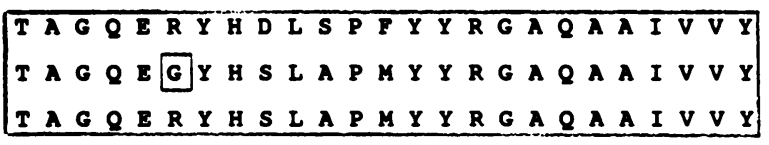 & $\begin{array}{l}100 \\
100 \\
100\end{array}$ \\
\hline $\begin{array}{l}\text { h-Rab5b } \\
\text { h-Rab5 } \\
\text { C-Rab5 }\end{array}$ & 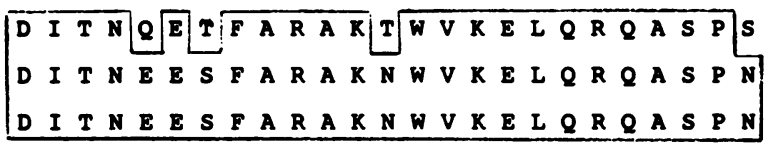 & $\begin{array}{l}125 \\
125 \\
125\end{array}$ \\
\hline $\begin{array}{l}\text { h-Rab5b } \\
\text { h-Rab5 } \\
\text { C-Rab5 }\end{array}$ & 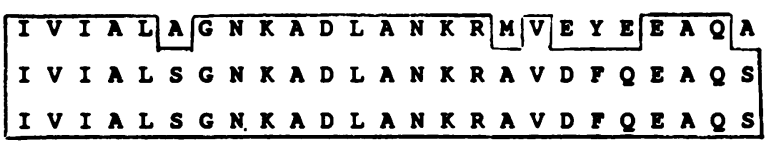 & $\begin{array}{l}150 \\
150 \\
150\end{array}$ \\
\hline $\begin{array}{l}\text { h-Rab5b } \\
\text { h-Rab5 } \\
\text { C-Rab5 }\end{array}$ & 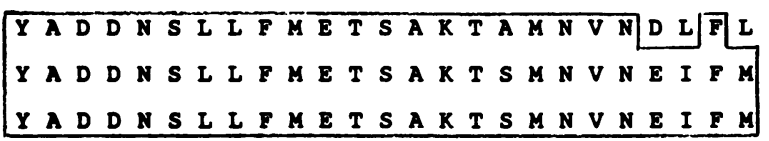 & $\begin{array}{l}175 \\
175 \\
175\end{array}$ \\
\hline
\end{tabular}

h-Rab5b AIAKXIPKSEPQNLGGAA G RS RGVD h-Rab5 c-Rab5

h-Rab5b

h-Rab5

c-Rab5

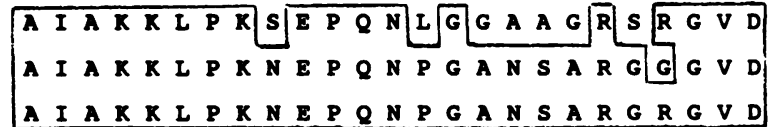

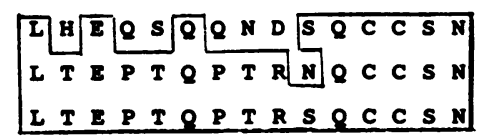

Figure 2. Comparison of the predicted amino acid sequences of human rab5b, human rab5, and canine rab5. Amino acids are shown in single letter code. Identical residues are boxed. Among the three proteins there is strict conservation in the sequences involved in guanine nucleotide binding: GESAVGK (residues 27-33), WDTAGQE (residues 74-80), NKAD (residues 133-136), and ETSAK (residues 161-165). Human rab5b diverges from the two rab5 sequences at the $\mathrm{NH}_{2}$ terminus (residues 1-16) and near the $\mathrm{COOH}$ terminus (residues 184-210). 
cation appears to reside in the last few amino acids of the proteins. In the case of the ras gene product, the $\mathrm{COOH}$-terminal sequence CAAX (where $\mathrm{A}$ is an aliphatic residue and $\mathrm{X}$ is any amino acid) specifies a set of posttranslational modifications (reviewed in reference 46). As shown in Fig. 2, human rab5b, human rab5, and canine rab5 end with the sequence QCCSN, which distinguishes these proteins from other members of the GTPase superfamily. Previous studies have demonstrated that deletion of the last four amino acids of canine rab5 disrupts normal membrane association and subcellular targeting (11). Given the similarities in sequence between rab5 and rab5b, it seems probable that the two proteins undergo the same posttranslational modifications. The exact nature of these modifications is presently unknown.

Although the predicted amino acid sequences of human rab5b and rab5 are highly homologous, the nucleotide sequences of the corresponding cDNAs are significantly different. In the coding regions the two cDNAs are $66 \%$ identical, whereas in the $5^{\prime}$ - and $3^{\prime}$-noncoding regions, the two cDNAs diverge widely. Partial sequencing of the exons of two overlapping human rab5b genomic clones failed to reveal any sequence deviations from the rab5b cDNA. Thus, the nucleotide (and amino acid) differences between rab5b and rab5 are not explained by polymerase errors during library construction or by naturally occurring polymorphisms.

Expression of rab5b $\mathrm{mRNA}$ in human cell lines. Like other members of the rab family, including rabs $2,4 \mathrm{a}, 4 \mathrm{~b}, 5,7$, and 9 (see references 5 and 7), rab5b mRNA was found to be expressed in a variety of cell types. Northern analysis under stringent conditions revealed a 3.6-kb mRNA hybridizing with the

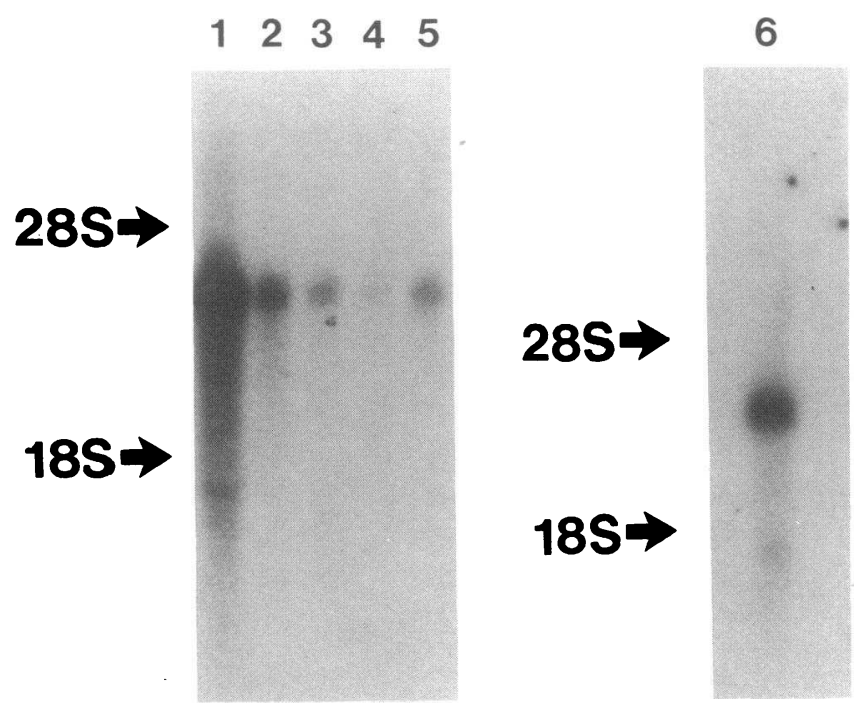

Figure 3. Northern analysis of rab5b expression in a variety of cell lines. Two Northern blots are shown. Lanes $1-5$ contained $20 \mu \mathrm{g}$ of total cell RNA; lane 6 contained $3 \mu \mathrm{g}$ of poly-A RNA. After electrophoresis, the RNA samples were transferred to Magnagraph (Micron Separations, Inc., Westboro, MA) and hybridized to a full length ${ }^{32} \mathrm{P}$ labeled rab5b cDNA probe. The migrations of 18- and 28-S rRNA are indicated. Lane 1, K562 cells; lane 2, K562 cells induced with hemin; lane 3, U937 cells; lane 4, human umbilical vein endothelial cells; lane 5, EA.hy926 cells; lane 6, HeLa cells. After autoradiography, the membranes were stripped and reprobed with a ${ }^{32} \mathrm{P}$-labeled $\alpha$-tubulin probe to confirm that equal amounts of mRNA were present in each lane (not shown).

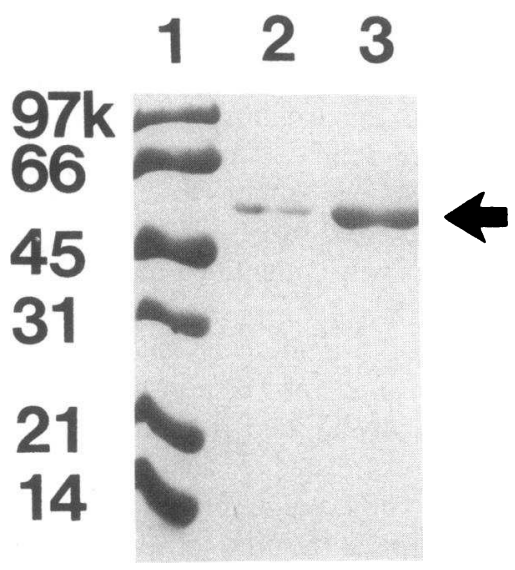

Figure 4. SDS-PAGE of purified GST-rab5b fusion protein. The fusion protein was isolated from $E$. coli by affinity chromatography on glutathione-agarose. The purified protein was run on SDS-PAGE under reducing conditions and visualized with Coomassie brilliant blue. Lane 1, molecular size standards; lane 2, 0.3 $\mu \mathrm{g}$ of affinity-purified GST-rab5b; lane 3, 1.5 $\mu \mathrm{g}$ of affinity-purified GST-rab5b. The fusion protein is indicated by an arrow.

rab5b probe in a variety of human cell lines, including K562 erythroleukemia cells, U937 monoblastic cells, human umbilical vein endothelial cells, EA.hy926 cells, and HeLa cells (Fig. 3). In K562 and HeLa cells, a faintly hybridizing band was also evident at $1.9 \mathrm{~kb}$. It is unclear whether this $1.9 \mathrm{~kb}$ reflects an alternatively processed rab5b RNA, a degradation product, or crosshybridization to another rab message. Previous studies have shown that hybridization of a human rab5 cDNA probe to fibroblast mRNA reveals two bands at 2.7 and $2.8 \mathrm{~kb}(7)$. These patterns of hybridization suggest that the rab5b probe does not cross-react significantly with rab5 mRNA under the hybridization conditions used in this study. Treatment of K562 cells with hemin, which induces expression of a number of genes, including globins, resulted in a decrease in the level of rab5b mRNA. This decrease was observed in two separate experiments.

Expression and purification of a rab5b fusion protein. A plasmid vector encoding a fusion protein between GST and human rab5b was prepared as described in Methods. This vector was used to transform $E$. coli, and bacterial synthesis of the fusion protein was induced by IPTG. The amount of GSTrab5b fusion protein produced by IPTG-treated bacteria was estimated by SDS-PAGE to be $5 \%$ of the total solubilized $E$. coli protein (not shown). The fusion protein had an apparent molecular size of $54 \mathrm{kD}$, reflecting the sum of the molecular sizes of GST, rab5b, and a 19-amino-acid linker peptide introduced during cloning. The fusion protein was purified to homogeneity by affinity chromatography on glutathione-agarose (Fig. 4).

GTP binding, GDP binding, and GTPase activity of rab5b. Purified GST-rab5b was transferred to nitrocellulose and incubated with $\left[\alpha-{ }^{32} \mathrm{P}\right] \mathrm{GTP}$ using a method that allows renaturation of GTP binding proteins. Autoradiography revealed binding of the labeled GTP to the fusion protein (Fig. 5, lane 1). No binding was seen to GST immobilized on nitrocellulose (lane 2). The binding of $1 \mu \mathrm{M}\left[\alpha-{ }^{32} \mathrm{P}\right] \mathrm{GTP}$ to GST-rab5b was blocked (>95\% inhibition) by $100 \mu \mathrm{M}$ unlabeled GDP but was not efficiently competed ( $<30 \%$ inhibition) by unlabeled $100 \mu \mathrm{M}$ ATP, CTP, or TTP (data not shown). These results suggest that rab5b specifically binds guanine nucleotides.

The binding and rate of dissociation of $\left[{ }^{3} \mathrm{H}\right] \mathrm{GDP}$ from GST-rab5b in solution was also measured using an exchange assay, as described in Methods. Fig. 6 shows the dissociation of 


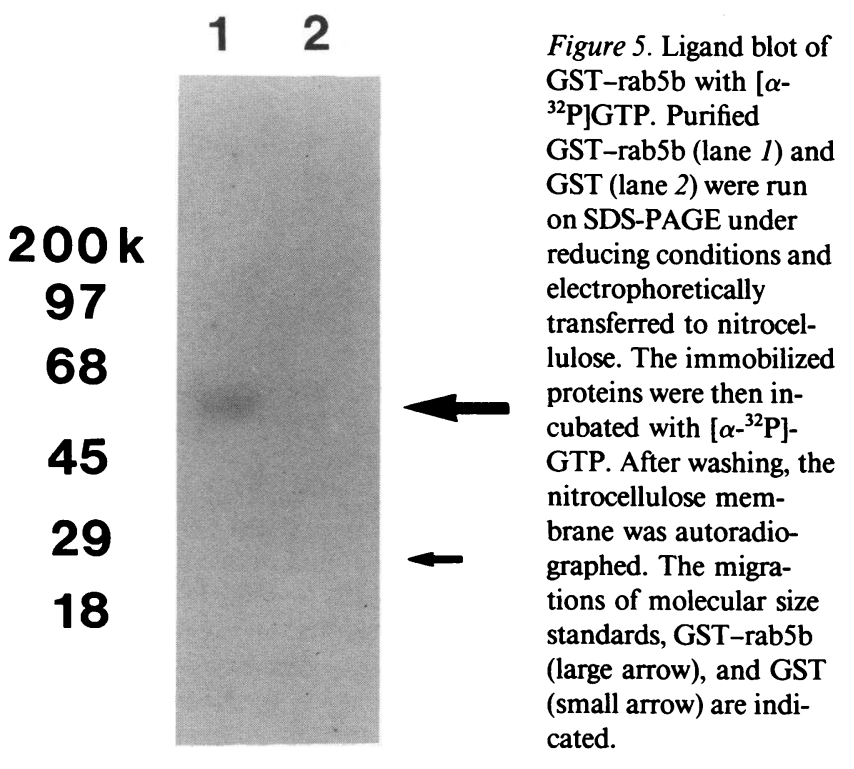

$\left[{ }^{3} \mathrm{H}\right]$ GDP from the fusion protein. $\left[{ }^{3} \mathrm{H}\right]$ GDP bound to GSTrab5b at $80 \%$ of the theoretical maximum (18.1 pmol of GDP/ $\mathrm{mg}$ protein), implying that the purified fusion protein retained most of its binding activity. A dissociation rate constant $\left(k_{-1}\right)$ of $0.8 \times 10^{2} / \mathrm{min}$ was calculated from the data in Fig. 6 . This $k_{-1}$ is comparable to the rate constants seen with other mammalian ras-related proteins (39).

The intrinsic GTPase activity of the GST-rab5b fusion protein was determined by incubating the purified protein in solution with $\left[\alpha-{ }^{32} \mathrm{P}\right] \mathrm{GTP}$ and measuring $\left[\alpha-{ }^{32} \mathrm{P}\right]$ GDP production. As shown in Fig. 7, the fusion protein exhibited a low rate of $\left[\alpha-{ }^{32} \mathrm{P}\right]$ GTP hydrolysis $(0.005 / \mathrm{mol})$. No hydrolysis was seen when purified GST was incubated with $\left[\alpha_{-}{ }^{32} \mathrm{P}\right] \mathrm{GTP}$. The low rate of GTP hydrolysis observed for GST-rab5b is comparable to the rates of hydrolysis $(0.005-0.05 / \mathrm{mol})$ observed for other rab fusion proteins (7). Several factors probably account for the low rates of hydrolysis exhibited by these bacterial fusion proteins, including $(a)$ nonspecific inhibition of hydrolysis by foreign protein in the fusion constructs, $(b)$ lack of the proper posttranslational modifications, and $(c)$ absence of cofactor/effector molecules (e.g., GTPase-activating proteins) in the reaction mixtures.

Western blotting of rab5b expressed in cells. An antiserum recognizing the hypervariable domain of rab5b was prepared by immunizing rabbits with a peptide corresponding to amino acids 184-197. This region of the rab5b molecule was chosen as an antigen to minimize cross-reactivity with other members of the small monomeric GTPase family. In this portion of the protein, human rab5b is identical to human rab5 in only 6 of 14 residues. Western blot analysis using rab5b antiserum and a preimmune serum control is shown in Fig. 8. The anti-rab5b serum was found to recognize the bacterial GST-rab5b fusion protein (Fig. 8, pair 1 ). The antiserum did not react with a total cellular extract (containing cytoplasmic and membrane fractions) from $\operatorname{COS}$ cells mock transfected with the eukaryotic expression vector pMT2 (Fig. 8, pair 2), indicating that the antiserum does not react indiscriminately with $\mathrm{COS}$ cell proteins (including other small monomeric GTPases). COS cells transfected with the expression construct pMT2-rab5b were found to synthesize a $25-\mathrm{kD}$ protein recognized by the antiserum but not by preimmune serum. This $25-\mathrm{kD}$ protein was evident in both the membrane and cytosolic fractions (Fig. 8 , pairs 3 and 4). The antiserum also detected a less prominent $32-\mathrm{kD}$ protein in the membrane and cytosolic extracts of transfected COS cells. The nature of this $32-\mathrm{kD}$ band is currently unknown. Possible explanations for the $32-\mathrm{kD}$ band include an unusual posttranslational modification of rab5b or an artifact of the COS overexpression system. Prenylation and carboxylmethylation are unlikely to account for the $32-\mathrm{kD}$ protein, as these modifications do not generally alter the apparent molecular size on SDS-PAGE. Nor does ubiquitinization of rab5b seem likely to account for larger band, since Western blotting with an antiserum recognizing ubiquitin-protein conjugates (generously provided by A. Schwartz, Washington University) failed to react with the 32-kD band (data not shown). Identif-

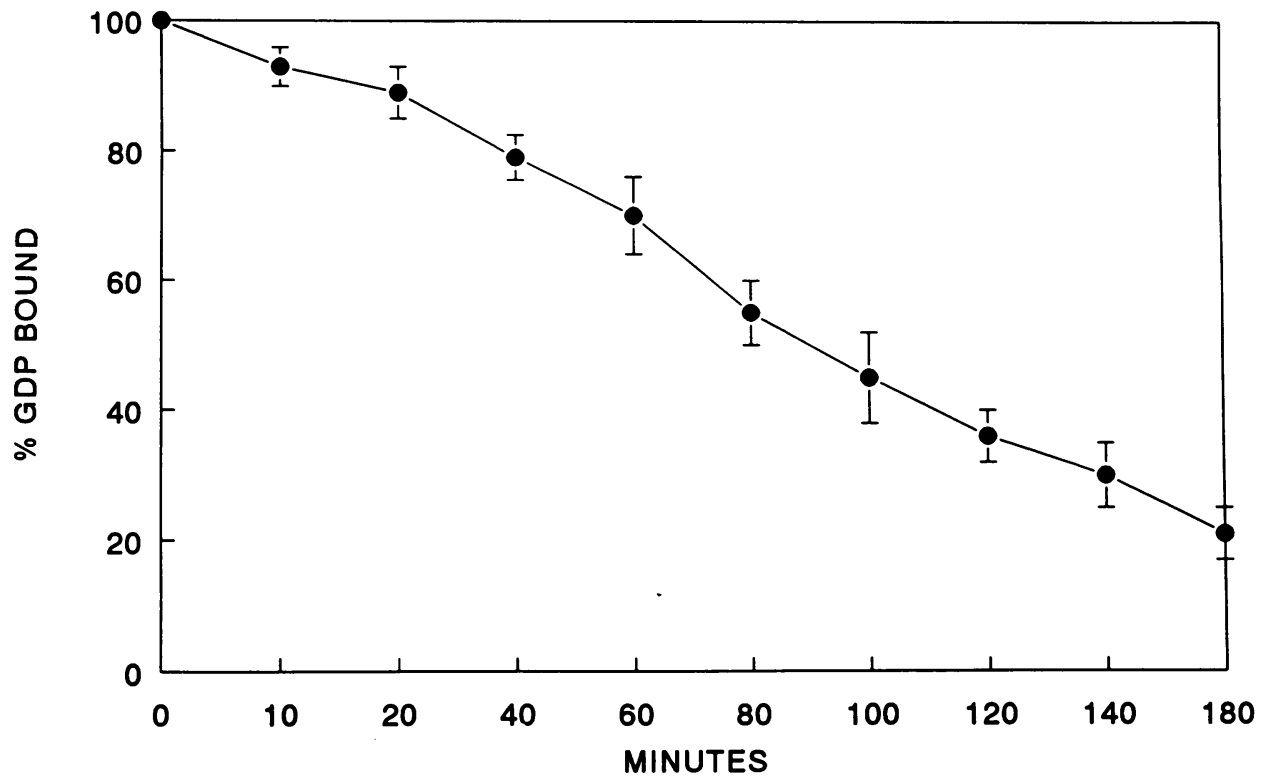

Figure 6. Dissociation of $\left[{ }^{3} \mathrm{H}\right] \mathrm{GDP}$ from GST-rab5b. [ $\left.{ }^{3} \mathrm{H}\right] \mathrm{GDP}(10 \mu \mathrm{M})$ was preincubated with $2 \mu \mathrm{M} \mathrm{GST}$ rab5b in the presence of $10 \mathrm{mM}$ $\mathrm{Mg}^{2+}$. At time zero, a large molar excess of unlabeled GDP was added. $\left[{ }^{3} \mathrm{H}\right]$ GDP remaining bound to GST-rab5b was determined using a nitrocellulose filter assay as described in Methods. The means of triplicate measurements are plotted in the graph. Standard deviations are indicated with error bars. 


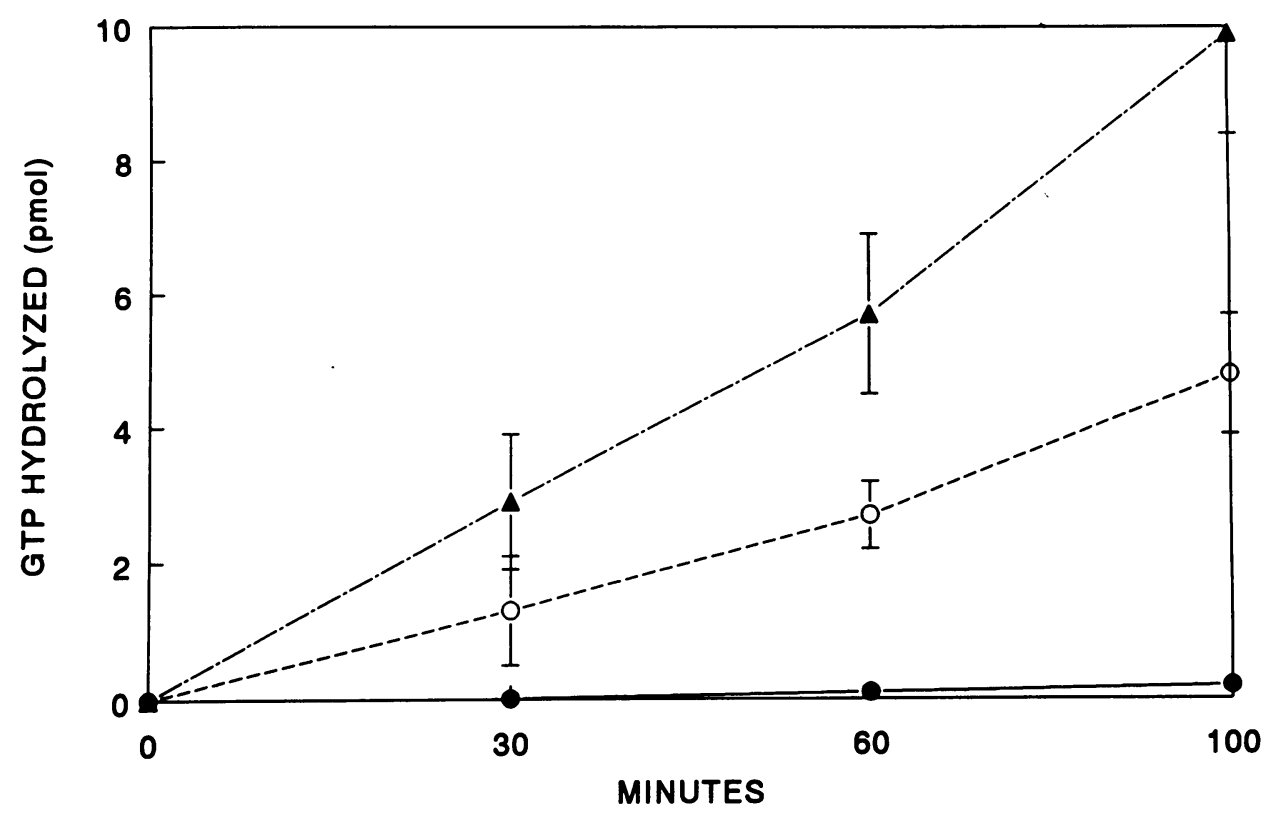

Figure 7. GTPase activity of GSTrab5b. $\left[\alpha{ }^{32} \mathrm{P}\right] \mathrm{GTP}(10 \mu \mathrm{M})$ was incubated for the indicated times with $2 \mu \mathrm{M}$ GST-rab5b ( $), 1 \mu \mathrm{M}$ GSTrab5b (o), or $2 \mu \mathrm{M}$ GST (॰). The incubation mixtures contained 10 $\mathrm{mM} \mathrm{Mg}{ }^{2+} \cdot\left[\alpha-{ }^{32} \mathrm{P}\right] \mathrm{GTP}$ hydrolysis was measured by thin layer chromatography as described in Methods. The means of triplicate measurements are plotted. Standard deviations are indicated with error bars. cation of the modifications present in the $32-\mathrm{kD}$ protein awaits further study. When cytosolic and membrane fractions from HeLa cells were subjected to Western blotting, a faint $25-\mathrm{kD}$ band was seen with immune but not with preimmune serum; in these cells staining of the $25-\mathrm{kD}$ band was more intense in the membrane fraction than in the cytosolic fraction (Fig. 8, pairs 5 and 6). No 32-kD band was seen in the HeLa extracts. We conclude that rab5b expressed in COS cells and HeLa cells has an apparent $M_{\mathrm{r}}=25 \mathrm{kD}$, in reasonable agreement with the molecular size predicted from the rab5b cDNA sequence $(23.7$ $\mathrm{kD})$. Moreover, we find that much of the rab5b in cells is present in the membrane fraction. With other members of the rab family, membrane association requires proper posttranslational modification. That a significant amount of rab5b is membrane associated suggests that the protein is undergoing posttranslational modification in COS and HeLa cells.

Immunohistochemistry of rab5b. In preliminary experiments we attempted to use indirect immunofluorescence with affinity-purified anti-peptide antibody to determine the subcellular distribution of rab5b in HeLa, human umbilical vein endothelial, and EA.hy926 cells. No significant immunofluorescent staining was observed in these cells, possibly because the amount of rab5b present is too small to be detected by this method. We therefore examined the distribution of rab5b in transfected COS cells, an approach that has permitted subcellular localization of other human proteins expressed in low amounts in nontransfected cells $(47,48)$. The immunofluorescent staining pattern of two COS cells transfected with pMT2rab5b is shown in Fig. 9. Only $3 \%$ of the COS cells examined by immunofluorescent staining expressed human rab5b. This transfection efficiency is typical for COS cells transfected by the DEAE dextran technique (47). Nontransfected COS cells in the microscopy fields served as negative controls, demonstrating that the affinity-purified antibody against human rab5b does not recognize any endogenous COS cell proteins. The cells expressing rab5b exhibited a dense rim of fluorescence, consis-

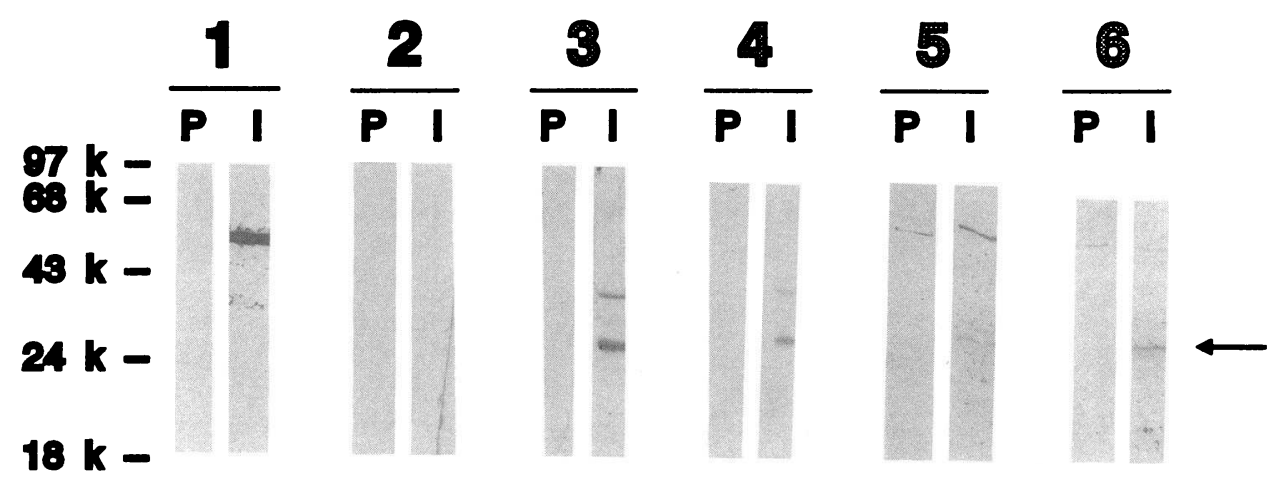

Figure 8. Western blots of rab5b expressed in cells. Purified GST-rab5b and various cell extracts were run on SDS-PAGE under reducing conditions and then transferred to nitrocellulose membranes for Western analysis. Six pairs of nitrocellulose strips are shown. The left strip of each pair was incubated with preimmune serum ( $P$, for preimmune), whereas the right strip was incubated with rab5b antiserum $(I$, for immune). Bound IgG was visualized with an alkaline phosphatase-conjugated second antibody. Pair 1, purified GST-rab5b $(1 \mu \mathrm{g})$; pair 2, total cell extract (membrane and cytosolic fractions) from COS cells mock transfected with pMT2; pair 3, cytosolic fraction (100,000 g supernatant) from COS cells transfected with pMT2-rab5b (25 $\mu \mathrm{g})$; pair 4, crude membrane fraction $(100,000 \mathrm{~g}$ pellet, containing nuclei and various membranes) from COS cells transfected with pMT2-rab5b (25 $\mu \mathrm{g})$; pair 5 , cytosolic fraction $(100,000 \mathrm{~g}$ supernatant) from nontransfected HeLa cells $(50 \mu \mathrm{g})$; pair 6 , crude membrane fraction $(100,000 \mathrm{~g}$ pellet, containing nuclei and various membranes) from nontransfected $\mathrm{HeLa}$ cells $(50 \mu \mathrm{g})$. The arrow indicates the $25-\mathrm{kD}$ immunoreactive protein presumed to be rab5b. In the pMT2-rab5b transformed COS cells, a second immunoreactive band is seen at $32 \mathrm{kD}$; the nature of this band is unclear. In HeLa cells, a $60-\mathrm{kD}$ protein reacting with both antiserum and preimmune serum is evident. 

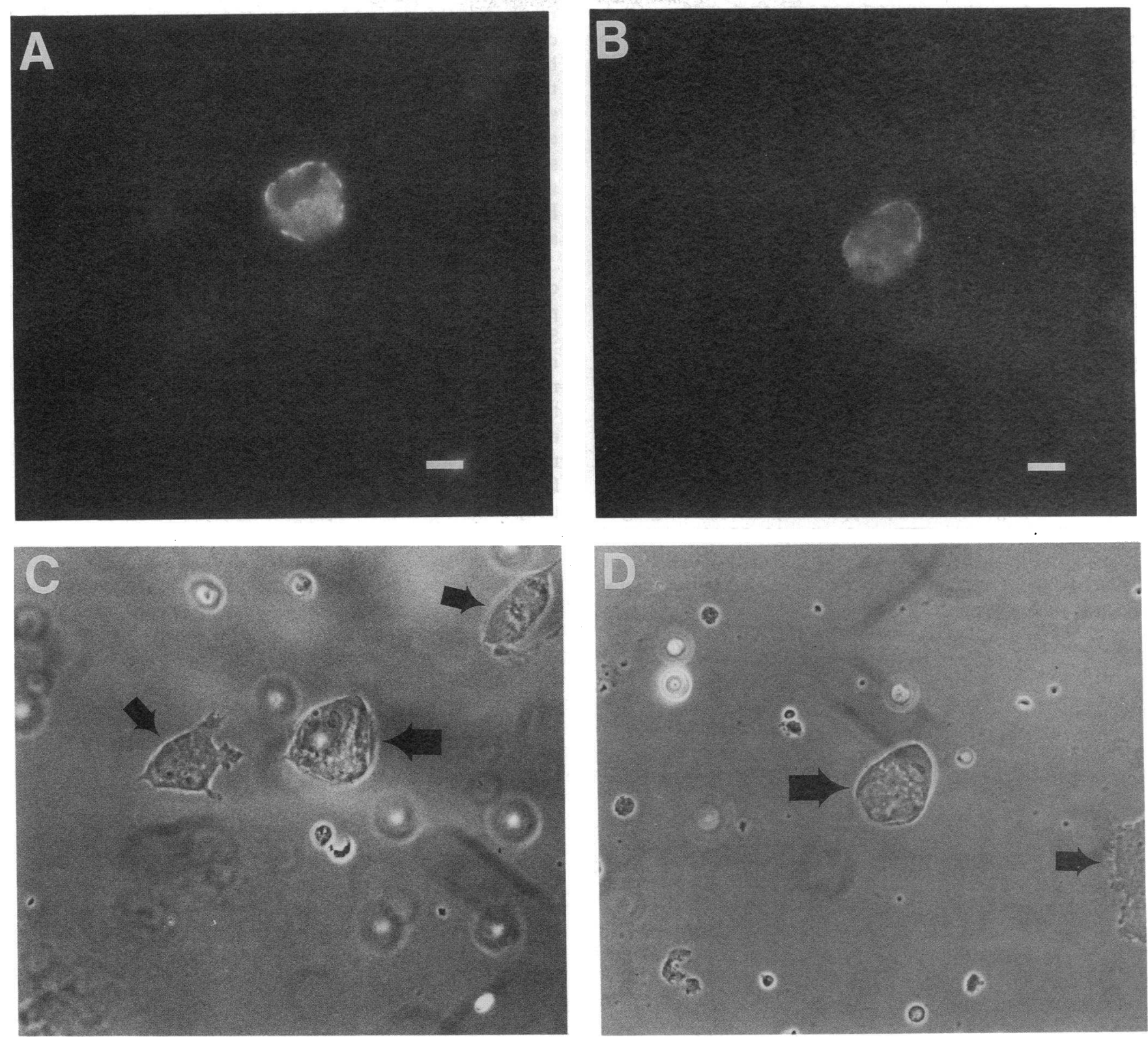

Figure 9. Immunofluorescent and phase contrast microscopy of COS cells expressing human rab5b. COS cells were transfected with pMT2-rab5b and incubated for $48 \mathrm{~h}$. The cells were then permeabilized, fixed, and stained with affinity-purified rab5b antibody followed by an FITC-labeled second antibody. Cells were examined by fluorescent and phase contrast microscopy. ( $A$ and $B$ ) Two separate fields of pMT2-rab5b-transformed cells viewed under fluorescence. ( $C$ and $D$ ) Corresponding fields viewed under phase contrast. The transfected COS cells (large arrows) appear larger than the surrounding nontransfected cells (small arrows) and exhibit a dense rim of plasma membrane staining. This plasma membrane staining is discontinuous. The nuclei of the transfected COS cells do not stain and appear black in the photomicrographs. Nontransfected cells show faint background (perinuclear) staining but no plasma membrane fluorescence. Bars, $10 \mu \mathrm{m}$.

tent with plasma membrane staining. In addition, faint staining of vesicular structures adjacent to the plasma membrane was evident in some of the transfected cells. By analogy to canine rab5b (11), this vesicular staining may reflect endosomes, although further experiments are required to demonstrate rigorously that rab5b is present in endosomes. COS cells mock transfected with pMT2 did not exhibit plasma membrane staining when examined by indirect immunofluorescence (not shown). To confirm that proteins destined for the plasma membrane were correctly targeted when overexpressed in COS cells, a control transfection was performed using an expression plasmid encoding the human Fc receptor. As anticipated, these transfected cells exhibited plasma membrane staining when stained with anti-Fc receptor antibody (not shown). As a negative control, COS cells were transfected with an expression plasmid encoding the transcription factor human GATA-2 and then subjected to indirect immunofluorescence. The expressed protein was seen in the cytoplasm and nucleus, but was not evident on the plasma membrane (not shown).

Subcellular fractionation of rab5b. Since overexpression may affect cellular organization and subcellular localization of 
rab5b, we sought verification that rab5b colocalizes with plasma membrane in nontransfected cells. HeLa cells were homogenized and fractionated on a Percoll gradient, and portions of the gradient were assayed for the marker enzymes $\beta-N$-acetylhexosaminidase (lysosomes), galactosyltransferase (Golgi), and ouabain-dependent $\mathrm{Na}^{+} \mathrm{K}^{+}$ATPase (plasma membrane). To determine the distribution of rab5b, samples from each fraction of the Percoll gradient were subjected to Western blotting after concentrating the membranes by centrifugation at $100,000 \mathrm{~g}$. The results of the subcellular fractionation are shown in Fig. 10. Membrane-bound rab5b was found to colocalize with the plasma membrane marker. Thus, rab5b localizes to plasma membrane in both transfected and nontransfected cells.

\section{Discussion}

We have isolated a cDNA clone encoding human rab5b, a new member of the ras-related superfamily of GTPases. Rab5b has a number of features that are characteristic of rab proteins and other ras-related GTPases. The size of rab5b, determined by Western blotting to be $25 \mathrm{kD}$, is typical of proteins belonging to the small monomeric GTPase family (20-25 kD). Like all members of the superfamily, rab5b contains a series of four conserved sequence motifs that contribute to the guanine nucleotide binding pocket. We have shown that a rab5b fusion protein binds guanine nucleotides in vitro and displays a low rate of GTP hydrolysis, comparable to the rates of hydrolysis seen with other rab fusion proteins. By Northern analysis, rab5b mRNA appears to be expressed in a wide variety of cell types, including erythroleukemia cells, monoblastic cells, carcinoma cells, and endothelial cells. With the notable exception of rab3a, which localizes to synaptic vesicles and adrenal chromaffin granules (14-17), most known rab proteins are expressed in many different cell and tissue types $(5,7)$.

Of the previously described rab proteins, rab5b is most closely related to rab5. Human rab5b and human rab5 are $81 \%$ identical in their amino acid sequences and have the same five amino acids at their $\mathrm{COOH}$ termini. As these $\mathrm{COOH}$-terminal amino acids are thought to signal modifications such as preny- lation and carboxylmethylation in other ras-related proteins, rab5b and rab5 may undergo similar posttranslational modifications (46). Immunohistochemical studies indicate that both human rab5b (this study) and canine rab5 (11) are found on the plasma membrane. Immunoelectronmicroscopy has shown that canine rab5b also localizes to early endosomes (11), and cell-free assays demonstrate that rab5 mediates early endosome fusion (25). Whether human rab5b is also capable of associating with endocytic vesicles and mediating endosome fusion awaits a more detailed ultrastructural and biochemical analysis.

The identification of a new member of the rab family that is closely related to a previously identified rab protein is not surprising. Approximately two dozen members of the rab/YPT1/ SEC4 family have been documented in various species, and new members of the family are emerging at a rapid rate. Closely related rab members ( $\mathrm{a}$ and $\mathrm{b}$ variants) have already been identified for rabs 1,3 , and $4(2,5,7)$. The reason for the existence of these pairs of molecules is presently unclear. To date, proteins belonging to these pairs have not been shown to differ from one another in tissue distribution, subcellular localization, or functional activity. Until additional studies are performed, the small differences in structure between these pairs of proteins cannot be dismissed as inconsequential; it is conceivable that these minor structural differences will prove to be of functional significance. The structures of " $a$ and b" variants of some rab proteins appear to be highly conserved across species lines, implying that these small structural differences have been retained through evolution (5-7, 11-17). A highly conserved $(>95 \%)$ analogue of human rab5b has not yet been identified in another species, although we speculate that such a protein is likely to exist.

As additional members of the rab family are identified, overlap in the subcellular distribution of these proteins is likely to be seen. Already, three different rabs $(4,5$, and $5 b)$ have been localized to the plasma membrane and adjacent vesicular structures $(11,12)$. The multiplicity of rab proteins in the plasma membrane raises the possibility that each protein plays a specialized role in this region of the cell.

Our future studies will aim at further defining the ultrastruc-

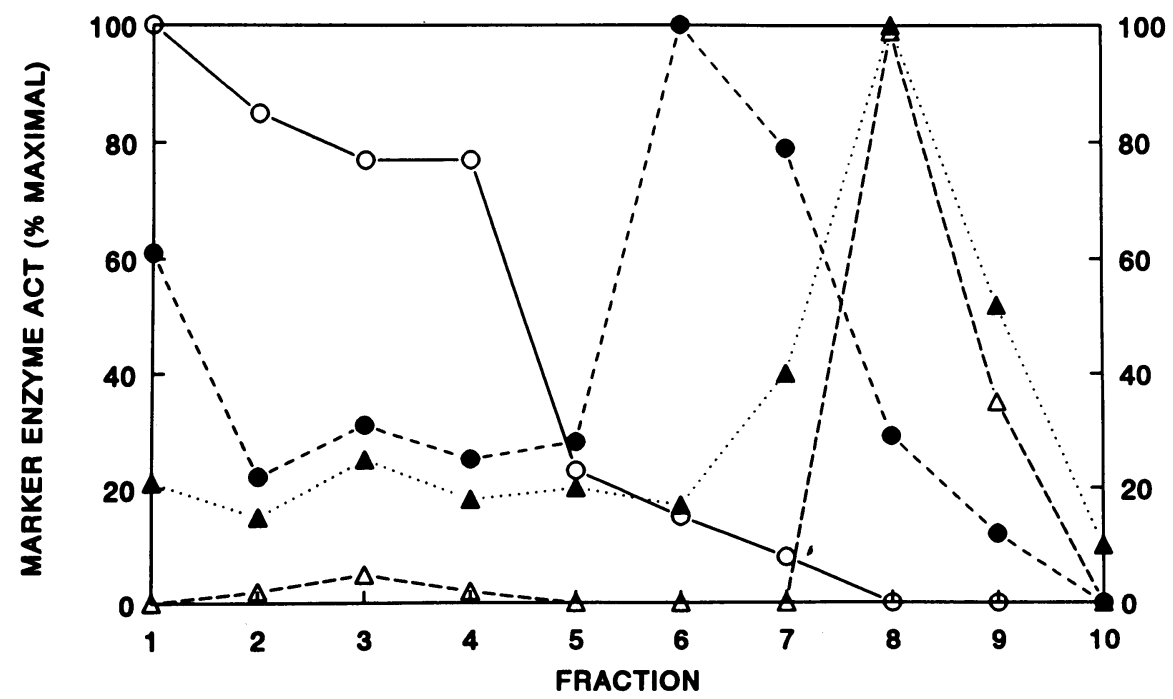

Figure 10. Subcellular distribution of rab5b in nontransfected HeLa cells. HeLa cells were homogenized and subjected to Percoll gradient centrifugation as described in Methods. Fractions from the gradient were assayed for lysosomal $(\beta-N$ acetylhexosaminidase; $O$ ), Golgi (galactosyltransferase; $\bullet$ ), and plasma membrane (ouabain-dependent $\mathrm{Na}^{+} \mathrm{K}^{+}$ATPase; $\left.\Delta\right)$ markers. The distribution of rab5b $(\Delta)$ was determined by Western blotting using ${ }^{125}$ I-labeled Protein A followed by phosphorimage analysis to quantitate the radioactive bands. The relative activities of the marker enzymes are plotted on the left axis as a percentage of maximal. The maximal activities for the marker enzymes

were as follows: $\beta$ - $N$-hexosaminidase, $19 \mathrm{nmol} / \mathrm{min}$ per $\mathrm{ml}$; galactosyltransferase, $11 \mathrm{nmol} / \mathrm{min}$ per $\mathrm{ml}$; and $\mathrm{Na}^{+} \mathrm{K}^{+} \mathrm{ATPase}, 12 \mathrm{nmol} / \mathrm{min}$ per $\mathrm{ml}$. Immunoreactive rab5b is expressed on the right axis as a percentage of maximal. The density of the gradient decreases from fraction 1 to fraction 10 . 
tural location of rab5b, determining posttranslational modifications of the protein, and identifying cofactor/target molecules. In addition, we will join other investigators in searching for novel members of the human rab family. Through these studies we hope to establish the role of rab proteins in membrane trafficking and explore the possibility of their involvement in disease states.

\section{Acknowledgments}

We thank Sabra Goff for oligonucleotide synthesis; David Dorfman for assistance with Northern blotting; Peter Tsai, Alan Ezekowitz, and Ellis Neufeld for technical advice; and Stuart Orkin and Irwin Levitan for support.

D. B. Wilson is supported by Public Health Service training grant 5P32HL-07574 from the National Institutes of Health (NIH). M. P. Wilson is supported by NIH grant NF-25366.

\section{References}

1. Bourne, H. R., D. A. Sanders, and F. McCormick. 1991. The GTPase superfamily: conserved structure and molecular mechanism. Nature (Lond.). 349:117-127.

2. Bourne, H. R., D. A. Sanders, and F. McCormick. 1990. The GTPase superfamily: a conserved switch for diverse cell functions. Nature (Lond.). 348:125-132.

3. Hall, A. 1990. The cellular functions of small GTP-binding proteins. Science (Wash. DC). 249:635-646.

4. Santos, E., and A. R. Nebreda. 1989. Structural and functional properties of ras proteins. FASEB (Fed. Am. Soc. Exp. Biol.) J. 3:2151-2163.

5. Chavier, P., M. Vingron, C. Sander, K. Simons, and M. Zerial. 1990 Molecular cloning of YPT1/SEC4-related cDNAs from an epithilium cell line. Mol. Cell. Biol. 10:6578-6585.

6. Touchot, N., P. Chardin, and A. Tavitian. 1987. Four additional members of the ras gene superfamily isolated by an oligonucleotide strategy: molecular cloning of YPT-related cDNAs from a rat brain library. Proc. Natl. Acad. Sci. USA. 84:8210-8214.

7. Zahraoui, A., N. Touchot, P. Chardin, and A. Tavitian. 1989. The human rab genes encode a family of GTP-binding proteins related to yeast YPT1 and SEC4 products involved in secretion. J. Biol. Chem. 264:12394-12401.

8. Balch, W. E. 1990. Small GTP-binding proteins in vesicular transport. Trends Biochem. Sci. 15:473-477.

9. Goud, B., and M. McCaffrey. 1991. Small GTP-binding proteins and their role in transport. Curr. Opin. Cell Biol. 3:626-637.

10. Bourne, H. R. 1988. Do GTPases direct membrane traffic in secretion? Cell. 53:669-671.

11. Chavrier, P., R. G. Parton, H. P. Hauri, K. Simons, and M. Zerial. 1990. Localization of low molecular weight GTP binding proteins to exocytic and endocytic compartments. Cell. 62:317-329.

12. van der Sluijs, P., M. Hall, A. Zahraoui, A. Tavitian, B. Goud, and I. Mellman. 1991. The small GTP-binding protein rab4 is associated with early endosomes. Proc. Natl. Acad. Sci. USA. 88:6313-6317.

13. Goud, B., A. Zahraoui, A. Tavitian, and J. Saraste. 1990. Small GTPbinding protein associated with Golgi cisternae. Nature (Lond.). 345:553-556.

14. Fisher von Mollard, G., G. A. Mignery, M. Baumert, M. S. Perin, T. J. Hanson, P. M. Burger, R. Jahn, and T. C. Südhof, T. C. 1990. Rab3 is a small GTP-binding protein exclusively localized to synaptic vesicles. Proc. Natl. Acad. Sci. USA. 87:1988-1992.

15. Avaki, S., A. Kikuchi, Y. Hata, M. Isomura, and Y. Takai. 1990. Regulation of reversible binding of smg p25A, a ras p21-like GTP binding protein, to synaptic plasma membranes and vesicles by its specific regulatory protein, GDP dissociation inhibitor. J. Biol. Chem. 265:13067-13015.

16. Fisher von Mollard, G., T. C. Südhof, and R. Jahn. 1991. A small GTPbinding protein dissociates from synaptic vesicles during exocytosis. Nature (Lond.). 349:79-81.

17. Darchen, F., A. Zahraoui, F. Hammel, M. Monteils, A. Tavitian, and D. Scherman. 1990. Association of the GTP-binding protein rab3a with bovine adrenal chromaffin cells. Proc. Natl. Acad. Sci. USA. 87:5692-5696.

18. Beckers, C. J. M., and W. E. Balch. 1989. Calcium and GTP: essential components in vesicular trafficking between the endoplasmic reticulum and Golgi apparatus. J. Cell. Biol. 108:1245-1256.

19. Bomsel, M., R. Parton, S. A. Kuznetsov, T. A. Schroer, and J. Gruenberg. 1990. Microtubule- and motor-dependent fusion in vitro between apical and basolateral endocytic vesicles from MDCK cells. Cell. 62:719-731.
20. Goda, Y., and S. R. Pfeffer. 1988. Selective recycling of the mannose-6-phosphate/IGF-II receptor to the trans Golgi network in vitro. Cell. 55:309-320.

21. Mayorga, L. S., R. Diaz, and P. D. Stahl. 1989. Regulatory role for GTPbinding proteins in endocytosis. Science (Wash. DC). 244:1475-1477.

22. Melançon, P., B. S. Glick, V. Malhotra, P. J. Weidman, T. Serafini, M. L. Gleason, L. Orci, and J. E. Rothman. 1987. Involvement of GTP-binding "G" proteins in transport through the Golgi stack. Cell. 51:1053-1062.

23. Tooze, S. A., U. Weib, and W. B. Hattner. 1990. Requirement for GTP hydrolysis in the formation of secretory vesicles. Nature (Lond.). 347:207-208.

24. Plutner, H., R. Schwaninger, S. Pind, and W. E. Balch. 1990. Synthetic peptides of the rab effector domain inhibit vesicular transport through the secretory pathway. EMBO (Eur. Mol. Biol. Organ.) J. 9:2375-2383.

25. Gorvel, J., P. Chavier, M. Zerial, and J. Gruenberg. 1991. Rab5 controls early endosome fusion in vitro. Cell. 64:915-925.

26. Salminen, A., and P. J. Novick. 1987. A ras-like protein is required for a post Golgi event in yeast secretion. Cell. 49:527-538.

27. Segev, N., J. Mulholland, and D. Botstein. 1988. The yeast GTP-binding YPT1 protein and a mammalian counterpart are associated with the secretion machinery. Cell. 52:915-924.

28. Schmitt, H. D., M. Puzicha, and D. Gallwitz. 1988. Study of a temperature-sensitive mutant of the ras-related YPT1 gene product in yeast suggests a role in the regulation of intracellular calcium. Cell. 53:635-647.

29. Ginsberg, D., R. I. Handin, D. T. Bonthron, T. A. Dunlon, G. A. P. Bruns, S. A. Latt, and S. H. Orkin. 1985. Human von Willebrand factor: isolation of complementary DNA clones and chromosomal location. Science (Wash. DC). 228:1401-1406.

30. Maniatis, T. E., E. F. Fritsch, and J. Sambrook. 1982. Molecular Cloning A Laboratory Manual. Cold Spring Harbor Laboratory, Cold Spring Harbor, NY. $545 \mathrm{pp}$.

31. Wilson, D. B., D. M. Dorfman, and S. H. Orkin. 1990. A nonerythroid GATA-binding protein is required for function of the human preproendothelin-1 promoter in endothelial cells. Mol. Cell. Biol. 10:4854-4862.

32. Sanger, F., S. Nicklen, and A. R. Coulson. 1977. DNA sequencing with chain-terminating inhibitors. Proc. Natl. Acad. Sci. USA. 74:5463-5467.

33. Tsai, S., D. I. K. Martin, L. I. Zon, A. D. D'Andrea, G. G. Wong, and S. H. Orkin. 1989. Cloning of cDNA for the major DNA-binding protein of the erythroid lineage through expression in mammalian cells. Nature (Lond.). 339:448451 .

34. Edgell, C. S., C. C. McDonald, and H. Graham. 1983. Permanent cell line expressing human factor VIII-related antigen established by hybridization. Proc. Natl. Acad. Sci. USA. 80:3734-3737.

35. Chromazynski, P., and N. Sacchi. 1987. Single-step method of RNA isolation by acid guanidinium thiocyanate-phenol-chloroform extraction. Anal. Biochem. 162:156-159.

36. Ausubel, F. M., R. Brent, R. E. Kingston, D. D. Moore, J. G. Seidman, J. A. Smith, and K. Struhl. 1989. Current Protocols in Molecular Biology. John Wiley and Sons, New York.

37. Laemmli, U. K. 1970. Cleavage of structural proteins during the assembly of the head of bacteriophage T4. Nature (Lond.). 227:680-685.

38. Schmitt, H. D., P. Wagner, E. Pfaff, and D. Gallwitz. 1986. The ras-related YPT1 gene product in yeast: a GTP-binding protein that might be involved in microtubule organization. Cell. 47:401-412.

39. John, J., M. French, and A. Wittinghofer. 1988. Biochemical properties of Ha-ras encoded p21 mutants and mechanism of autophosphorylation reaction. J. Biol. Chem. 263:1792-11799.

40. Harlow, E., and D. Lane. 1988. Antibodies: A Laboratory Manual. Cold Spring Harbor Press, Cold Spring Harbor, NY.

41. Yamamoto, M., L. J. Ko, M. W. Leonard, H. Beug, S. H. Orkin, and J. D. Engel. 1990. Activity and tissue specific expression of the transcription factor NF-E1 multigene family. Genes Dev. 4:1650-1662.

42. Morand, J. N., and C. Kent. 1986. A one-step technique for the subcellular fractionation of total cell homogenates. Anal. Biochem. 159:157-162.

43. Ohtakara, A. 1988. Purification of $\beta-N$-acetylhexosaminidase. Methods Enzymol. 161:463-467.

44. Rothman, J. E., and E. Fries. 1981. Transport of newly synthesized vesicular stomatitis viral glycoprotein to purified Golgi membranes. J. Cell. Biol. 89:162-168.

45. Bradford, M. M. 1976. A rapid and sensitive method for the quantitation of microgram quantities of protein utilizing the principle of protein-dye binding. Anal. Biochem. 72:248-254.

46. Glomset, J. A., M. H. Gelb, and C. C. Farnsworth. 1990. Prenyl proteins in eukaryotic cells: a new type of membrane anchor. Trends Biochem. Sci. 15:139-142.

47. Berger, J., A. D. Howard, L. Gerber, B. R. Cullen, and S. Udenfriend. 1987. Expression of active, membrane-bound human placental alkaline phosphatase by transfected simian cells. Proc. Natl. Acad. Sci. USA. 84:4885-4889.

48. Cheng, S. H., R. J. Gregory, J. Marshall, S. Paul, D. W. Souza, G. A. White, C. R. O'Riordan, and A. E. Smith. 1990. Defective intracellular transport and processing of CFTR is the molecular basis of most cystic fibrosis. Cell. 63:827-834. 